\title{
INSTRUMENTOS DA POLÍTICA URBANA E PRODUÇÃO DO ESPAÇO: ANÁLISE DA IMPLEMENTAÇÃO DO PARCELAMENTO, EDIFICAÇÃO E UTILIZAÇÃO COMPULSÓRIOS - PEUC E IPTU PROGRESSIVO NO TEMPO EM PALMAS - TOCANTINS
}

\begin{abstract}
Germana Pires Coriolano
Doutoranda em Planejamento Urbano e Regional pela Faculdade de Arquitetura e Urbanismo da Universidade de São Paulo (FAU-USP), São Paulo, SP, Brasil. germanapires@uft.edu.br

Ibrahin Amhed León Tellez
Doutor em Ciências Econômicas e professor da Universidad de Granma, Bayamo, Granma, Cuba.
ileont@udg.co.cu
\end{abstract}

Eduardo Alberto Cusce Nobre Doutor e Livre-Docente em Arquitetura e Urbanismo pela Faculdade de Arquitetura e Urbanismo da Universidade de São Paulo (FAU-USP), São Paulo, SP, Brasil. eduardonobre@usp.br

\begin{abstract}
RESUMO
A última capital planejada no Brasil desenvolveu-se seguindo uma lógica excludente, de ocupação esparsa e segregada, materializando uma configuração urbana de baixíssima densidade, com um alto custo de urbanização e a população de menor renda à margem do espaço planejado. 0 objetivo deste trabalho é compreender de que forma os instrumentos da política urbana, especialmente PEUC e IPTU Progressivo, vêm sendo implantados no intuito de reverter a lógica da ocupação insustentável do solo urbano de Palmas. Observou-se na análise que, durante o processo de planejamento temas como: a dispersão urbana, a segregação e o alto custo de urbanização da cidade, são definidos como parte dos principais problemas existentes e, apesar da legislação apresentar avanços, não há efetividade na aplicação dos instrumentos, não revertendo (ou enfrentando) a lógica capitalista de produção da cidade.
\end{abstract}

Palavras-chave: Instrumentos da política urbana. PEUC. IPTU progressivo no tempo. Palmas - TO.

\section{URBAN POLICY INSTRUMENTS AND SPACE PRODUCTION: ANALYSIS OF IMPLEMENTATION OF COMPULSORY SUBDIVISION, BUILDING OR UTILIZATION OF LAND (CSBU AND TIME PROGRESSIVE URBAN LAND TAX IN PALMAS - TOCANTINS}

\begin{abstract}
This article aims to discuss the application Compulsory Subdivision, Building or Utilization of Land (CSBU), as well as Time Progressive Urban Land Tax in Palmas - Tocantins. The last planned capital in Brazil was developed following an exclusionary, sparse and segregated occupation logic, materializing a very low density urban configuration, with a high cost of urbanization and a lower income population on the fringes of planned space. The objective of this paper is to understand how urban policy instruments, especially Compulsory Subdivision, Building or Utilization of Land (CSBU) and Time Progressive Urban Land Tax, have been implemented in order to reverse the logic of unsustainable occupation of the urban land of Palmas. It was observed in the analysis that, during the planning process, themes such as: urban sprawl, segregation and the high cost of urbanization of the city are defined as part of the main existing problems and, although the legislation presents advances, there is no effectiveness in application of the instruments, not reversing (or facing) the capitalist logic of the city's production.
\end{abstract}

Keywords: instruments of urban policy. Compulsory Subdivision, Building or Utilization of Land (CSBU). Time progressive urban land tax. Palmas - TO. 


\section{INTRODUÇÃO}

Alguns autores afirmam que para compreender a natureza da cidade capitalista é necessário analisála como fruto de um processo dinâmico e dialético, comandado pelas classes dominantes, processo esse que faz com que a cidade seja ao mesmo tempo palco para o encontro das pessoas e produto desse encontro, que a partir de suas relações sociais e econômicas a refaz e a reproduz conforme suas necessidades e contradições (CARLOS, 2007; CORREA, 1989).

Dessa forma, para a compreensão da problemática urbana, faz-se necessário analisar a forma de produção da cidade, compreendendo-a, segundo Lefebvre (2009), como lócus de reprodução do sistema capitalista, uma vez que entendemos que este é o motor das transformações das sociedades surgidas a partir do contexto da modernidade, além de ser o indutor dos problemas relativos ao crescimento e à planificação urbanos.

A cidade pode ser considerada como produto do capitalismo, fruto também dos processos sociais de transformação (HARVEY, 2006). Enquanto produto de transformação social, a cidade é produzida a partir da ação dos diversos atores: os cidadãos comuns, os movimentos sociais organizados, os agentes do capital (proprietários dos meios de produção, proprietários fundiários, o promotores imobiliários - incluindo o mercado da construção civil e incorporação) e o Estado (representantes do poder público), tendo como resultado as intervenções físicas no território e a sua regulação. (CORREA, 1989)

No modo de produção capitalista da cidade, a terra urbana se torna uma mercadoria, que segue as "leis" estabelecidas pelo mercado, sendo o seu valor resultado de vários fatores, mas principalmente da sua infraestruturação e localização. A distribuição da população no território se dá a partir de sua renda, cujo efeito perverso desse processo reproduz na cidade uma divisão territorial da sociedade, o perfil socioeconômico da população define zonas sociais, resultando em uma conexão entre a configuração urbana e o padrão de desigualdades que prevalecem na cidade, pois segundo Ribeiro: "É a vigência dos clássicos mecanismos de acumulação urbana, cujos fundamentos são as próprias desigualdades cristalizadas na ocupação do solo" (RIBEIRO, 2005, p. 47).

O resultado desse processo é uma cidade estruturada a partir da segregação sócio-espacial, tal qual relatado por Villaça (1998). Importante notar, que em sociedades periféricas ao capitalismo, como a Brasileira, onde as desigualdades sociais e de distribuição de renda são maiores, essa estruturação segregada e fragmentada é mais evidente e aguda do que nas cidades dos países centrais.

Ao longo do século $\mathrm{XX}$, as cidades brasileiras sofreram um intenso processo de urbanização. Em menos de 50 anos, passamos de uma sociedade rural para atualmente chegarmos a um índice superior a $84 \%$ da população morando nas áreas urbanas. Esse processo se caracterizou principalmente pela migração da população de baixa renda para as cidades e acabou por concentrá-la em espaços sem qualidade adequada. $O$ resultado disso foi a constituição de um país marcado por fortes desigualdades sócio-espaciais, com uma cidadania ambígua e grande parcela da população à margem de seus direitos (MARICATO, 2000; ROLNIK, 2007).

Estas desigualdades provocaram nas cidades uma série de problemas urbanísticos, sociais e ambientais, acentuados a partir das décadas de 1950 e 1960, com o processo de intensa urbanização. A atuação política de movimentos sociais e profissionais preocupados com esses problemas, agregados em torno do Movimento Nacional de Luta pela Reforma Urbana, resultou durante o período da redemocratização na inclusão do Capítulo da Política Urbana na Constituição Federal de 1988 e posteriormente a sua regulamentação, através da promulgação do Estatuto da Cidade - Lei Federal no 10.257 de 2001.

O Estatuto, associado à criação do Ministério das Cidades e do Conselho Nacional das Cidades, ambos em 2003, representaram marcos institucionais importantes para o estabelecimento de uma Política Nacional de Desenvolvimento Urbano com controle social, possibilitando a criação de diversos programas de desenvolvimento urbano, como a Campanha Nacional dos Planos Diretores Participativos, que apoiou os municípios na elaboração de seus planos diretores.

Neste contexto, o Município de Palmas elaborou o Plano Diretor Participativo de Palmas (PDPP), aprovado em dezembro de 2007, sendo este o primeiro marco municipal de aplicação dos instrumentos da política urbana pós-Estatuto da Cidade, onde se estabeleceu pela primeira vez o Parcelamento, Edificação e Utilização Compulsórios (PEUC) e o Imposto Predial e Territorial (IPTU) Progressivo no tempo como estratégias para adensamento e ocupação ordenada do território. 
Este artigo busca analisar a aplicação do deste instrumento enquanto estratégia para promover o adensamento e ocupação sustentável do território. A metodologia deste trabalho se baseia em uma abordagem qualitativa, a partir da análise documental da legislação acerca da temática, amparada por uma abordagem quantitativa a partir dos dados disponíveis sobre a aplicação do instrumento no território. A leitura teórico-conceitual tem como ponto de partida o materialismo histórico dialético, que se baseia em uma análise crítica dos processos de produção do espaço urbano, dos avanços e retrocessos na aplicação dos instrumentos da política urbana no território.

\section{BREVE CARACTERIZAÇÃO DE PALMAS}

Palmas, a mais nova capital do país, foi criada para ser a sede administrativa do Estado do Tocantins em 1989 a partir de um projeto de povoamento e desenvolvimento regional para o Planalto Central do País. Com uma população estimada em 2019 de 299.127 habitantes e uma área territorial de 2.218,937 $\mathrm{km}^{2}$, Palmas teve incremento demográfico de $66,2 \%$ de população e um taxa de crescimento anual de $5,22 \%$ entre 2000 a 2010 , sendo a capital com a maior taxa de crescimento, passando de 137.355 para 228.332 habitantes.

De acordo com a estimativa do IBGE (2019) a tendência de crescimento na última década reduziu, tendo a taxa de crescimento anual caído para $3,05 \%$, bem menor do que a expectativa dos planejadores, mas maior do que a média nacional, sendo a segunda capital que mais cresceu no Brasil, com taxa inferior a Boa Vista (RO), que recebe um grande contingente de imigrantes venezuelanos.

\begin{tabular}{|c|c|c|c|c|}
\hline Ano & 1991 & 2000 & 2010 & 2019 \\
\hline População & 24.334 & 137.355 & 228.332 & 299.127 \\
\hline $\begin{array}{l}\text { Taxa de Crescimento da } \\
\text { População (\% a.a) }\end{array}$ & - & $21,20 \%$ & $5,22 \%$ & $3,05 \%$ \\
\hline
\end{tabular}

Fonte: IBGE: Censos de 1991, 2000 e 2010, e Estimativa 2019

Apesar de crescer com uma das maiores taxas de crescimento do país, Palmas é a capital que tem a menor população e o menor tempo de existência, tendo completado agora seus 30 anos com problemas semelhantes às cidades não planejadas brasileiras. Ainda assim, acredita-se que seja possível corrigir a ocupação desordenada do território, que embora tenha surgido a partir de um plano urbanístico, teve seu processo de ocupação muito diferente do planejado.

No início de sua implantação, as terras escolhidas foram desapropriadas pelo Estado, transformando o Executivo Estadual no maior proprietário fundiário do município. Nessa perspectiva, ele comercializava as propriedades fundiárias junto ao capital imobiliário e utilizava as terras urbanas para negociar o pagamento das empreiteiras responsáveis pelas obras de construção da cidade. Dessa forma, o Governo do Estado do Tocantins adotou uma política de reserva de terras na região central e induziu a ocupação das áreas periféricas com loteamentos populares, provocando um processo de especulação e valorização imobiliária da região central, agenciado pelo próprio Estado (MORAES, 2003; CORIOLANO, 2011).

O Plano Diretor Urbanístico de Palmas - PDUP1 previa uma densidade mínima de 300 habitantes por hectare, racionalizando a implantação da infraestrutura. Planejou-se uma ocupação por etapas sequenciais, na qual, com a ocupação de todas as áreas, a cidade chegaria a 38.400 hectares podendo abrigar aproximadamente 2,5 milhões de habitantes (Figura 01).

\footnotetext{
${ }^{1}$ Lei Municipal no 468 de 06 de janeiro de 1994 - Lei 468/94 - Plano Diretor Urbanístico de Palmas (PDUP), Artigo $7^{\circ}, \S 1$.
} 
Figura 01 - Palmas (TO): Proposta de ocupação urbana sequenciada

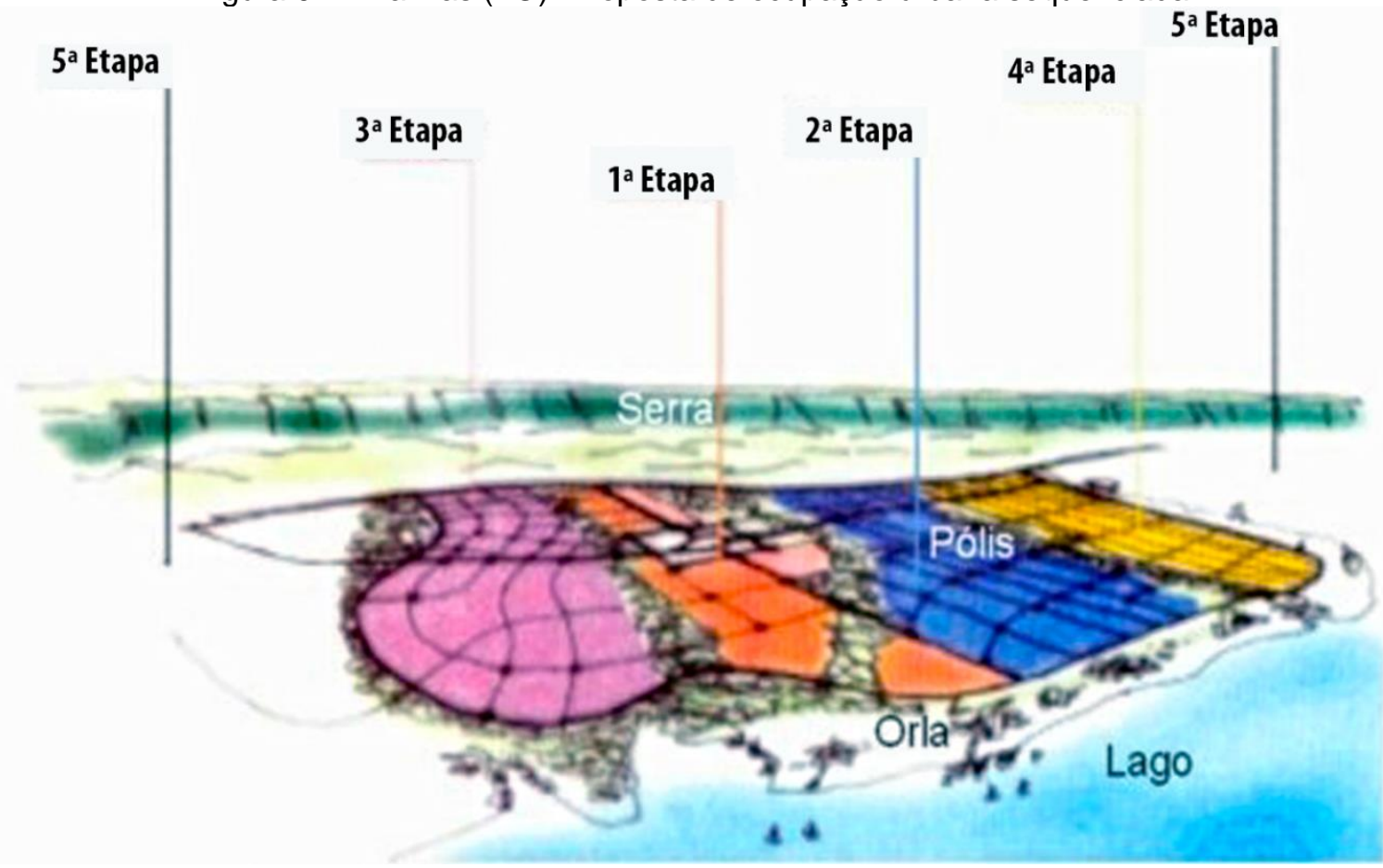

Fonte: Caderno Revisão do Plano Diretor de Palmas (PALMAS, 2005).

Apesar de ficar clara a intenção de promover uma ocupação ordenada e sequenciada, a evolução da ocupação urbana desconsiderou o planejamento da cidade, já no início da implantação, conforme se pode observar na Figura 2, abaixo. Com o aumento do número de imigrantes, o Estado colocou barreiras policiais nas entradas da cidade com o intuito de direcionar a população de baixa renda para a região sul, à revelia do plano urbanístico. A implantação da cidade ocorreu, por consequência, de maneira esparsa, provocando vazios urbanos e a prática da especulação imobiliária (PALMAS, 2001; CORIOLANO, 2011).

Como se pode observar na Figura 02, a ocupação das áreas periféricas se deu logo no início do processo de implantação da cidade. Em 1990 já se observava o adensamento da região do Taquaralto, impulsionada pelo próprio Estado ao direcionar os trabalhadores para aquele local, longe da área planejada, prevista para uma expansão posterior à ocupação das quatro primeiras etapas e até 1995 a cidade já tinha uma ocupação desordenada, tendo ocupado de maneira dispersa todas as etapas previstas para serem ocupadas de forma sequenciada (Palmas, 2005).

Palmas, como se observa na Figura 03 predomina uma ocupação com densidade inferior a 12 habitantes por hectare. Estudos realizados pelo Banco Interamericano de Desenvolvimento - BID, na elaboração do Programa Iniciativa Cidades Emergentes Sustentáveis (ICES) com base em dados do Censo do IBGE (2010), apontam que a densidade urbana líquida é de 36,71 hab/ha, longe da densidade idealizada pelo plano original, que seria de $300 \mathrm{hab} / \mathrm{ha}$, configurando uma cidade esparsa, com uma baixíssima densidade e consequentemente um alto custo de urbanização. (PALMAS; BID; POLIS; 2015). 
Figura 02 - Histórico dos Parcelamentos de Palmas

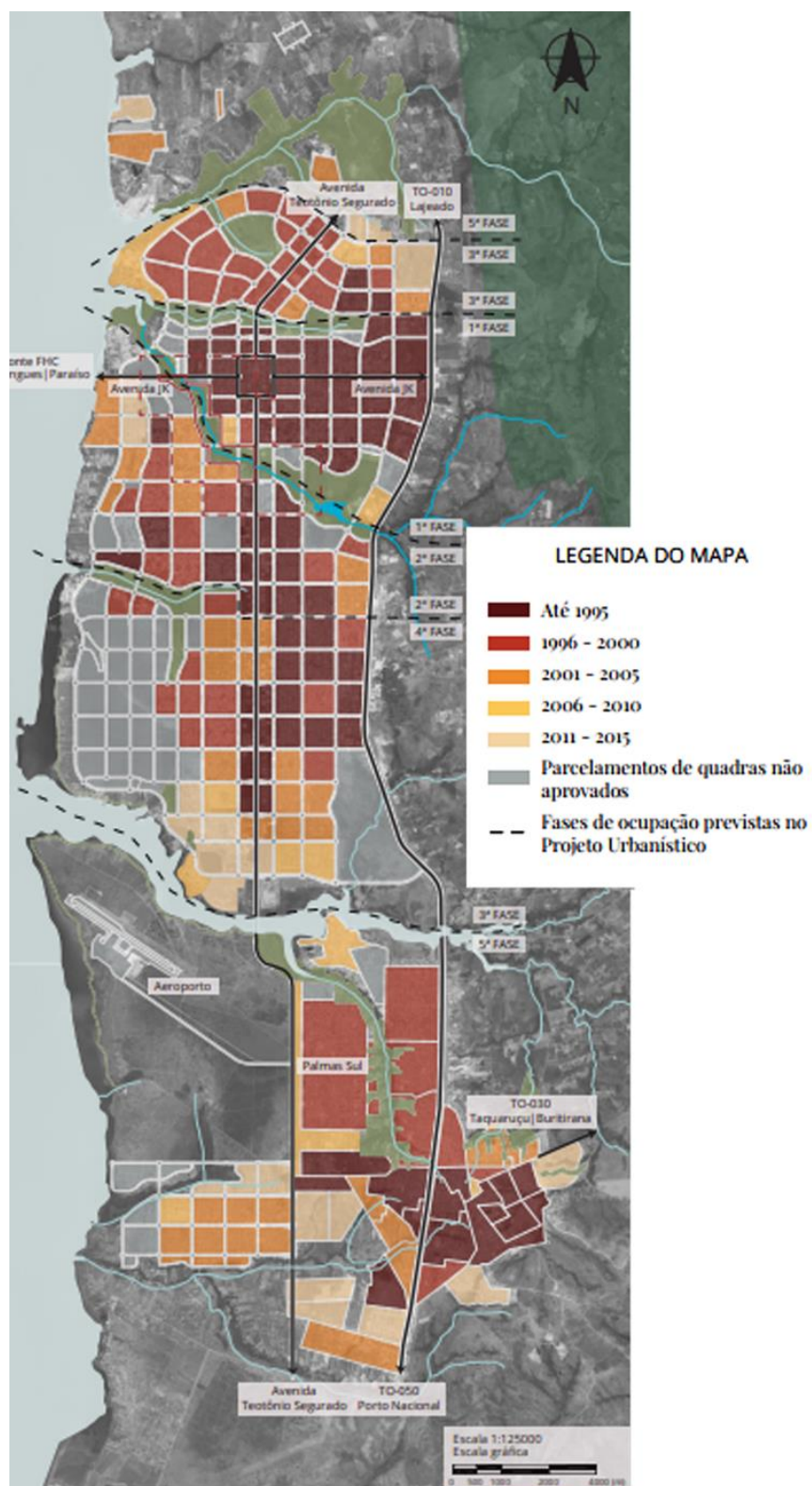

Fonte: SEMDUS (2015). Elaborado por CORDEIRO, 2019
Figura 03 - Densidade Urbana

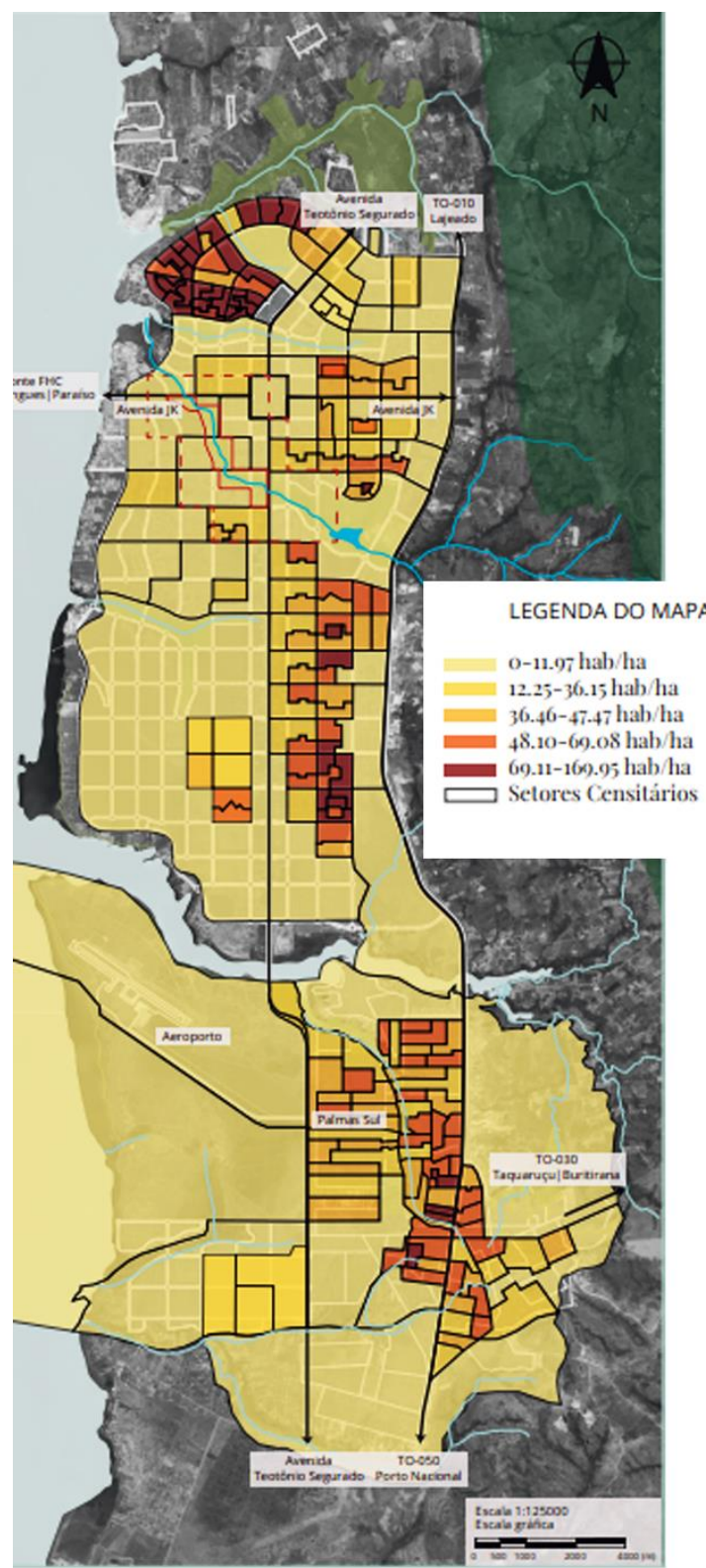

Fonte: IBGE (Censo 2010) elaborado por CORDEIRO, 2019.

Prevista para expansão posterior, a Região Sul abriga aproximadamente $50 \%$ da população urbana de Palmas, concentrando uma maior quantidade de pessoas com menor poder aquisitivo e também as áreas de menor valor venal, como se pode observar nas figuras 04 e 05 . Este cenário mostra claramente a segregação das famílias de baixa renda em áreas periféricas da cidade, nas áreas não planejadas, configurando "o lugar dos pobres" na cidade dita planejada. 
Figura 04 - Renda média da população

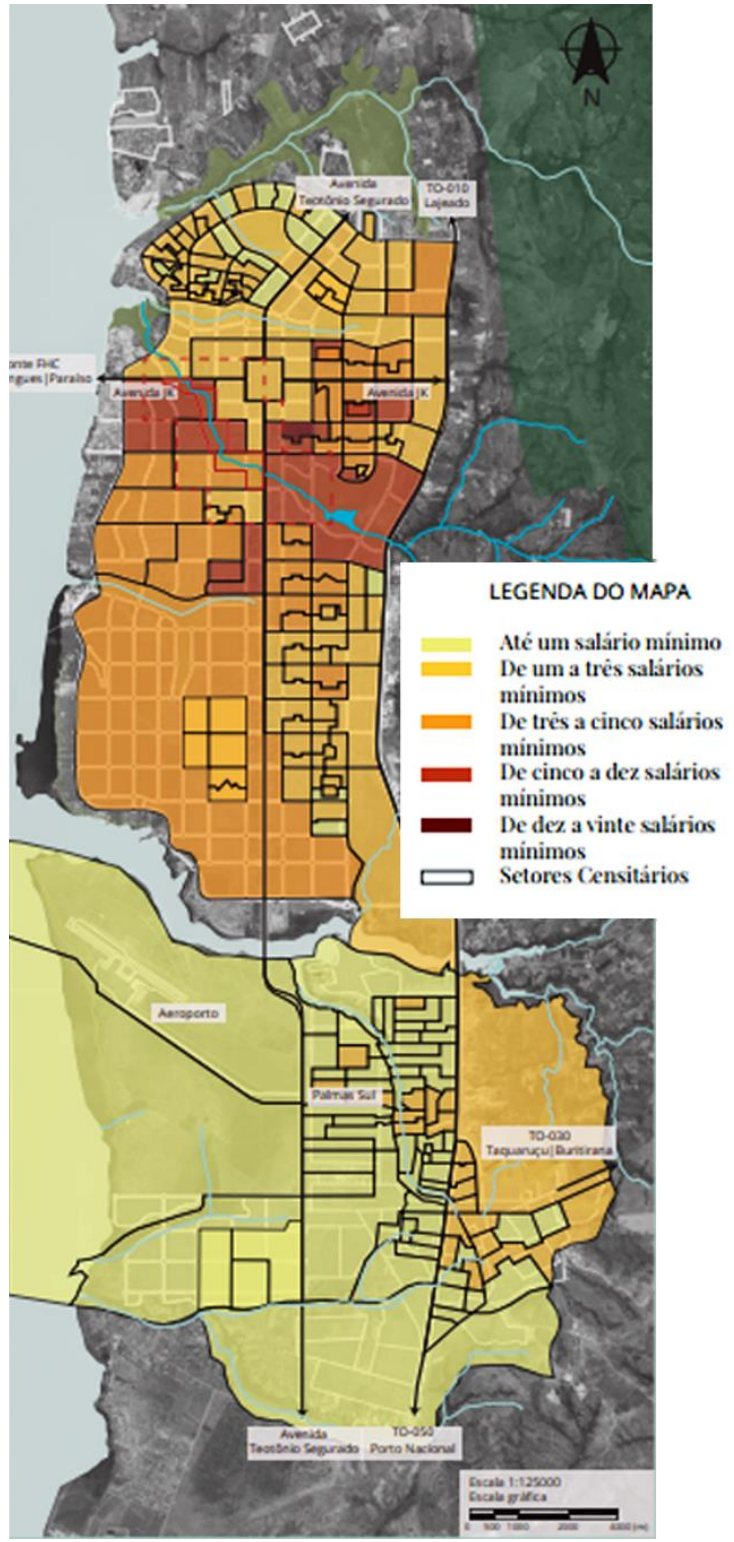

Fonte: IBGE, Censo 2010, elaborado por CORDEIRO (2018).
Figura 05 - Valor do solo urbano

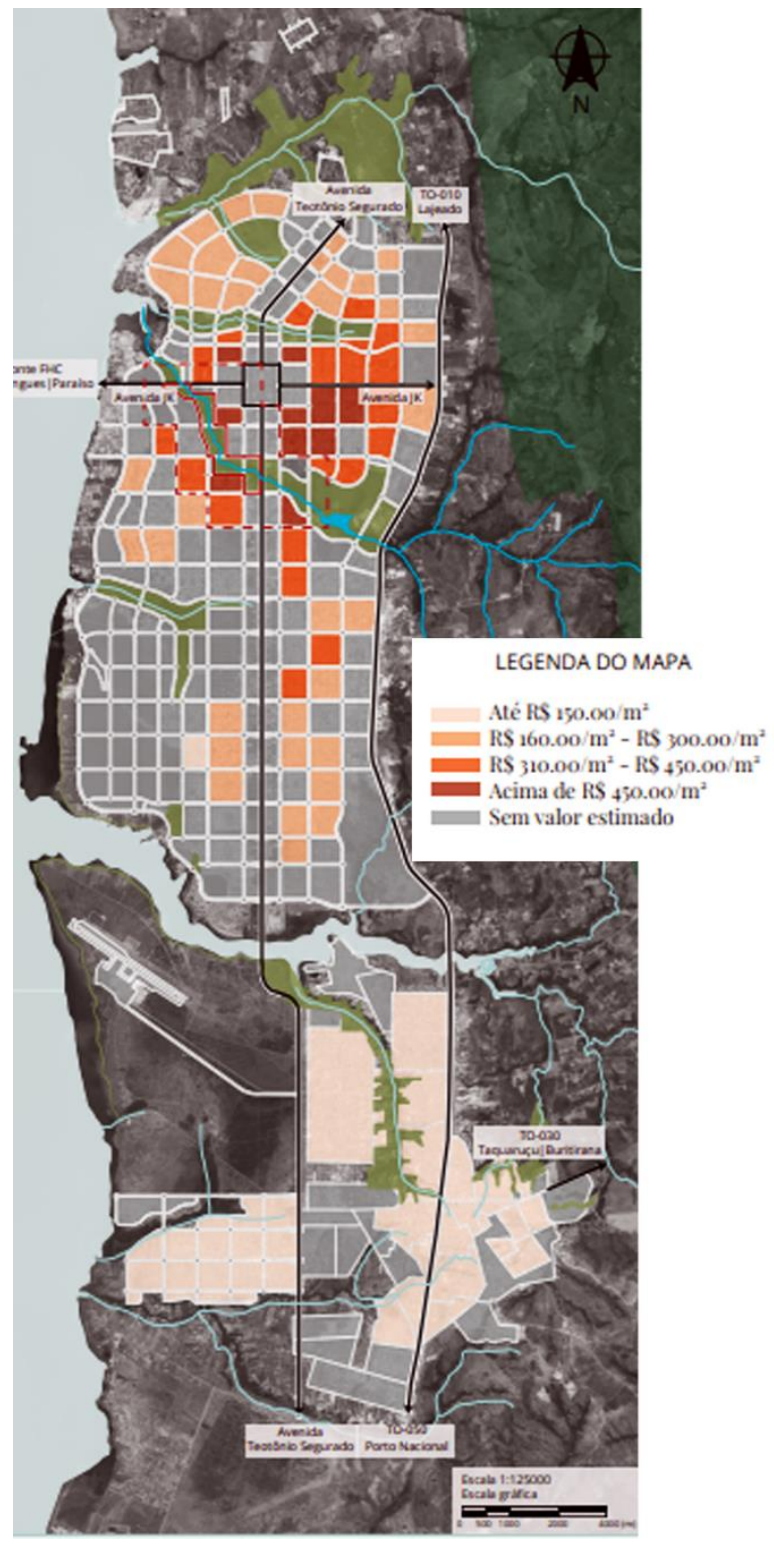

Fonte: Planta de valores genéricos 2013, elaborado por CORDEIRO (2018)

\section{OS MARCOS NORMATIVOS DA POLÍTICA URBANA BRASILEIRA}

A Constituição da República Federativa do Brasil - CF aprovada em 1988, também conhecida como "Constituição Cidadã", é o primeiro marco legal da política urbana no Brasil (MARICATO e SANTOS JÚNIOR, 2007). Este importante instrumento jurídico propôs a descentralização do poder administrativo do Governo Federal, repassando aos municípios as responsabilidades que antes pertenciam à União. Em seu Capítulo IV é estabelecida uma série de competências para os municípios. O inciso VII deste capítulo estabelece que compete ao município "promover, no que couber, adequado ordenamento territorial, mediante planejamento e controle do uso, do parcelamento e da ocupação do solo urbano", onde fica clara a responsabilidade dos municípios frente à questão urbana (BRASIL, Art. 30, 1988).

Durante a década de 1980 observa-se no Brasil uma grande mobilização dos movimentos populares movimentos sociais e profissionais no sentido de enfrentar o quadro das desigualdades sociais e dos problemas urbanos já em pauta desde as décadas anteriores. Dentre os que se organizaram, principalmente no contexto da elaboração da Constituição e em busca da instituição de direitos sociais, 
estava o Movimento Nacional de Luta pela Reforma Urbana - MNRU, constituído por organizações não-governamentais, entidades de classe, movimentos de moradia e sindicatos.

Este movimento apresentou a Emenda Popular no 63/1987, conhecida como "Emenda Popular da Reforma Urbana", subscrita com 131 mil assinaturas (GRAZIA, 2003; DUQUE BRASIL, 2011). Apesar de não ter sido totalmente incorporada ao texto constitucional, não deixou de ser relevante para a instituição de uma política urbana. Este movimento resultou, durante o período da redemocratização, na inclusão do Capítulo da Política Urbana na Constituição Federal de 1988, que estabeleceu o princípio da Função Social da Propriedade e da Cidade, que para diversos autores representou um grande avanço ao submeter o interesse individual ao coletivo, muito embora tenha submetido tal princípio ao Plano Diretor, contrariando a proposta da Emenda (GRAZIA, 2003, RIBEIRO, 2003).

$\mathrm{Na}$ nova Constituição, o Princípio da Função Social da Propriedade apresenta-se como peça fundamental para a proposta de reforma urbana e o uso mais justo do território, estabelecido no inciso XXIII do Artigo 5o, no âmbito dos direitos e garantias fundamentais do cidadão, onde se estabelece que "a propriedade atenderá a sua função social".

A Constituição brasileira trouxe, portanto, grandes transformações ao Direito de Propriedade, pois no mesmo artigo que o garante, determina sua subordinação à observância de sua função social. Ou seja, o uso e gozo deste direito passam a estar condicionados ao interesse geral da sociedade, que deve prevalecer sobre o interesse individual. Posteriormente, em seu art. 170 a CF estabelece a função social da propriedade como princípio de ordem econômica, articulando-a com a função de ordenação da propriedade privada.

A mesma Carta dispõe também sobre a função social da cidade, porém não explica de que forma a cidade poderá cumpri-la. Quanto à função social da propriedade urbana, ela determina que esta deva ser definida no Plano Diretor de cada município.

Art. 182. A política de desenvolvimento urbano, executada pelo Poder Público municipal, conforme diretrizes gerais fixadas em lei, tem por objetivo ordenar o pleno desenvolvimento das funções sociais da cidade e garantir o bem- estar de seus habitantes.

$\S 1^{\circ}$ - O plano diretor, aprovado pela Câmara Municipal, obrigatório para cidades com mais de vinte mil habitantes, é o instrumento básico da política de desenvolvimento e de expansão urbana.

$\S 2^{\circ}$ - A propriedade urbana cumpre sua função social quando atende às exigências fundamentais de ordenação da cidade expressas no plano diretor ${ }^{2}$. (BRASIL, 1988).

Todavia, a norma Constitucional estabeleceu no parágrafo $4^{\circ}$, do artigo supramencionado, alguns instrumentos inovadores. No caso da propriedade não cumprir com sua função social o município poderá cobrar do proprietário que "promova seu adequado aproveitamento, sob pena, sucessivamente, de":

I - parcelamento ou edificação compulsório;

II - imposto sobre a Propriedade Predial e Territorial urbana progressivo no tempo;

III - desapropriação com pagamento mediante títulos da dívida pública de emissão previamente aprovada pelo Senado Federal, com prazo de resgate de até 10 anos, em parcelas anuais, iguais e sucessivas, assegurados o valor real da indenização e os juros legais. (BRASIL, 1988).

Além de estabelecer o princípio da Função Social da Cidade e da Propriedade e a obrigatoriedade de instituição do Plano Diretor como instrumento básico da política de desenvolvimento e de expansão urbana, a Constituição ainda afirmou a responsabilidade dos municípios frente à política de desenvolvimento e gestão urbanos. O que efetivamente é de difícil aplicabilidade, pois a observância desta responsabilidade demanda aos Municípios maior capacidade técnica e de gestão administrativa e os governos locais são marcados por intensas desigualdades.

A regulamentação do capítulo da política urbana da CF deu-se através da promulgação da Lei Federal no 10.257 de 2001. O Estatuto da Cidade, "estabelece normas de ordem pública e interesse social que regulam o uso da propriedade urbana em prol do bem coletivo, da segurança e do bem-estar dos

\footnotetext{
${ }^{2}$ Grifo nosso.
} 
cidadãos, bem como do equilíbrio ambiental"3. O Estatuto tem por objetivo estabelecer diretrizes gerais da política urbana, que, por sua vez, visa ordenar o pleno desenvolvimento das funções sociais da cidade e da propriedade, reforça o Plano Diretor como instrumento básico da política de desenvolvimento e expansão urbana e amplia a obrigatoriedade para cidades integrantes de aglomerações urbanas e regiões metropolitanas, inseridas em áreas de especial interesse turístico, áreas de significativo impacto ambiental ou ainda aquelas nas quais o poder público pretenda utilizar os instrumentos definidos no $\S 4^{\circ}$ do Art. 182 da CF, que trata do devido aproveitamento do solo urbano.

Apesar de definir as diretrizes gerais para o cumprimento da função social da cidade e da propriedade urbana, o princípio que a estabelece continua em aberto, sendo remetido aos planos diretores. Há de se considerar também que a quantidade de diretrizes de caráter geral não encara com objetividade a realidade dos municípios brasileiros, dessa forma ao elaborarem seus planos diretores incorporam estas diretrizes de forma genérica, sem uma avaliação mais coerente de acordo com a realidade local e sem articulação com o uso e a ocupação do território (SANTOS JÚNIOR et al., 2011).

As inovações trazidas pelo Estatuto da Cidade se dividem em três campos: o primeiro refere-se aos instrumentos urbanísticos voltados para indução do modo de uso e ocupação do solo; o segundo diz respeito aos instrumentos de regularização fundiária e o terceiro aos instrumentos de gestão democrática da cidade (IDEM, IBDEM).

Para a maioria dos urbanistas e pesquisadores urbanos a lei foi um grande avanço para o planejamento e gestão das cidades, por abrir possibilidades para a promoção da inclusão socioterritorial e para a implementação da reforma urbana a partir da aplicação das diretrizes e dos instrumentos de gestão voltados para garantir o direito à cidade e a sua gestão democrática.

\section{INSTRUMENTOS DA POLÍTICA URBANA: PEUC E IPTU PROGRESSIVO}

Os instrumentos da política urbana são responsáveis por regular o uso e a ocupação do solo urbanos, de acordo com Souza (2010, p. 217) "os instrumentos típicos do Urbanismo são, juntamente com o zoneamento de uso e ocupação do solo, os vários tipos de índices e parâmetros que regulam a densidade e a forma de ocupação do espaço."

O Estatuto da Cidade estabelece uma série de instrumentos com o objetivo de garantir o desenvolvimento das funções sociais da cidade e da propriedade urbana, inclusive tributários e financeiros, como é o caso do IPTU progressivo no tempo, que será abordado a seguir. Estes instrumentos vão além da sua função de arrecadação: têm a capacidade de permitir que diferentes objetivos sejam alcançados, tais como a promoção da redistribuição indireta de renda, a orientação e o disciplinamento da expansão urbana, o adensamento ou o incentivo a determinadas atividades em regiões específicas da cidade.

O Parcelamento, Edificação ou Utilização Compulsórios - PEUC tem como principal objeto combater a especulação imobiliária e o alto custo da infraestrutura e serviços urbanos, fazendo com que a terra urbana cumpra a sua função social. Este instrumento já estava previsto na Constituição Federal, se constituindo como a primeira penalidade pela retenção ociosa de terrenos urbanos. (BASSUL, 2002)

A segunda penalidade prevista na Lei é a aplicação do IPTU Progressivo no Tempo para os imóveis que não cumpram com a primeira exigência estabelecida pela aplicação do PEUC. O instrumento prevê a progressão da alíquota de IPTU, até o dobro de seu valor de um exercício para outro, chegando ao teto máximo de $15 \%$. Passados cinco anos de cobrança do IPTU progressivo no tempo, o município poderá promover a Desapropriação com Pagamento em Títulos da Dívida Pública. (IDEM, IBDEM)

\section{A CF, no $\S^{\circ}$ do artigo 182, estabelece que:}

§ 4ํㅡ facultado ao poder público municipal, mediante lei específica para área incluída no plano diretor, exigir, nos termos da lei federal, do proprietário do solo urbano não edificado, subutilizado ou não utilizado que promova seu adequado aproveitamento, sob pena, sucessivamente, de:

I - parcelamento ou edificação compulsórios;

II - imposto sobre a propriedade predial e territorial urbana progressivo no tempo;

III - desapropriação com pagamento mediante títulos da dívida pública (...).

\footnotetext{
${ }^{3}$ Lei No 10.257 , de 10 de julho de 2001 - Estatuto da Cidade, Art. $1^{\circ}$, parágrafo único.
} 
Instrumentos da política urbana e produção do espaço: análise da implementação do parcelamento, edificação e utilização compulsórios

- PEUC e IPTU progressivo no tempo em Palmas - Tocantins
Germana Pires Coriolano Ibrahin Amhed León Tellez Eduardo Alberto Cusce Nobre

Estes três instrumentos devem ser aplicados de forma sucessiva e tem como objetivo o combate à especulação imobiliária e consequentemente a ampliação de terras no mercado. O Estatuto define que a aplicação dos instrumentos depende da criação de lei específica, mas prevê que a elaboração dos planos diretores devem obrigatoriamente prever a delimitação de áreas para aplicação do PEUC.

Em pesquisa realizada pelo Instituto de Pesquisas Econômicas Aplicadas, publicada em 2015, dos municípios com população acima de cem mil habitantes, somente oito deles estavam aplicando o PEUC e somente dois tinham naquele momento iniciado o lançamento do IPTU Progressivo no tempo (IPEA, 2015).

\section{A APLICAÇÃO DO PEUC E IPTU PROGRESSIVO EM PALMAS}

O primeiro marco normativo para a aplicação do Parcelamento Edificação e Utilização Compulsórios e do IPTU progressivo no tempo em Palmas foi o Plano Diretor Participativo de Palmas - PDPP, Lei Complementar no 155/2007. O Capítulo II, do Título VII do PDPP estabeleceu que todos os imóveis subutilizados, em áreas dotadas de infraestrutura, localizadas nas Áreas de Ocupação Prioritária e Preferencial (Figura 06) seriam passíveis de aplicação de Parcelamento, Edificação e Utilização Compulsórios (PEUC), seguidos do IPTU Progressivo no Tempo e da Desapropriação com Pagamentos em Títulos.

Os instrumentos objetivam proporcionar o uso adequado aos imóveis ociosos e estabelecer a forma de notificação, devendo ainda instituir o prazo máximo de um ano, para que os proprietários de imóveis nesta situação protocolem na Prefeitura um processo para aprovação de projeto de parcelamento ou edificações. O prazo para início das obras se estende por mais dois anos a partir da aprovação do projeto. Ou seja, todo o proprietário teria no mínimo três anos para dar um uso adequado ao imóvel.

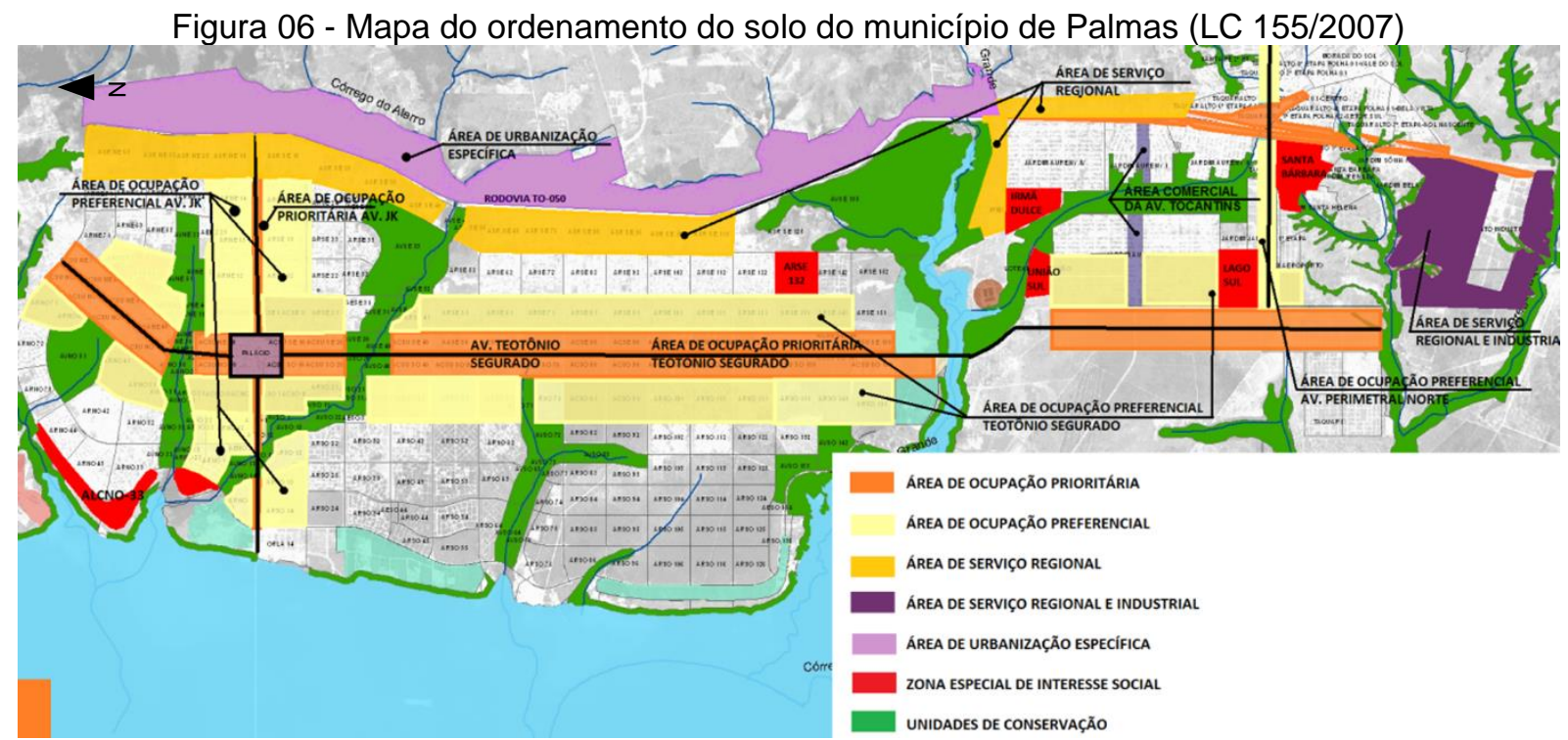

Fonte: SEDUH, Prefeitura de Palmas (2007), adaptado.

A Lei traz a definição para imóvel subutilizado e/ou não utilizado, que configura:

I - aquele cuja área construída seja inferior a 10\% da área permitida para edificação no lote;

II - aquele cujo investimento na edificação for incompatível com o valor do lote, ou seja, cujo investimento seja inferior ao preço do lote;

III - edificações que tenham permanecido sem uso por período igual ou superior a 05 (cinco) anos;

IV - lotes ou glebas vazias em áreas dotadas de infra-estrutura básica tais como: água e esgotamento sanitário, energia e acesso por vias pavimentadas e transporte coletivo acessível a menos de 800 metros. (PALMAS, LEI COMPLEMENTAR № 155/2007, Art. $\left.75, \S^{\circ}\right)$. 
O Imposto Predial e Territorial Urbano Progressivo no Tempo é uma penalidade para os proprietários que não fizerem o uso adequado dos terrenos, devendo ser cobrado durante cinco anos, se o proprietário não der o devido uso ao imóvel, o município poderá desapropriá-lo com pagamentos em títulos da dívida pública. A alíquota no Plano foi graduada da seguinte forma:

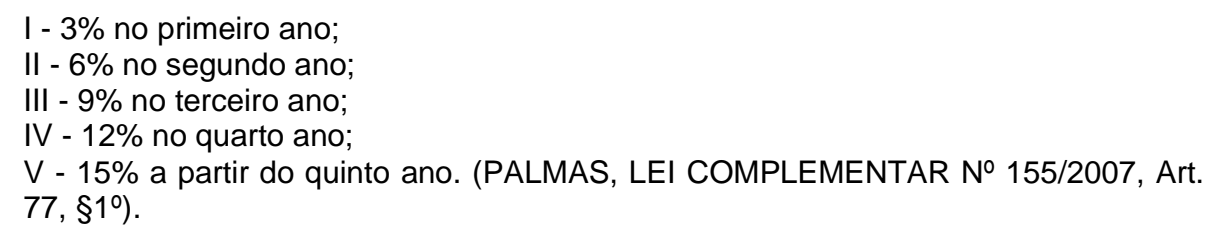

Apesar da alíquota ter sido definida no PDPP, o artigo que a definiu foi revogado pela Lei Complementar no 195/2009, remetendo esta definição para o Código Tributário Municipal (Lei Complementar no 107/2005), que por sua vez não deixou claro as alíquotas de aplicação do instrumento, inviabilizando a sua aplicação naquele momento. Somente em 2014 as alíquotas de progressividade foram estabelecidas pela Lei Complementar no 296 de 03/07/2014, que em seu artigo $1^{\circ}$ alterou o artigo $4^{\circ}$ da LC195/2009 e também a LC no 155/2007 (Plano Diretor Participativo), definindo o critério de progressividade, sendo definido como o dobro do valor do ano anterior, o máximo permitido pelo Estatuto da Cidade, conforme pode-se observar a seguir:

Art. 1ㅇ O art. 4 da Lei Complementar 195 , de 22 de dezembro de 2009, passa a vigorar com a seguinte redação:

"Art. 4ํㅡ Em caso de descumprimento das condições, das etapas e dos prazos previstos para parcelamento, edificação e utilização compulsórios, a Prefeitura aplicará, nos imóveis notificados, o Imposto sobre a Propriedade Predial e Territorial Urbana - IPTU progressivo no tempo, com a alíquota, em cada ano, correspondente ao dobro da alíquota do ano anterior."

A LC no 195/2009 já havia regulamentado o Parcelamento, Edificação ou Utilização Compulsórios PEUC, normatizando e estabelecendo etapas sucessivas para as notificações, obedecendo inicialmente às áreas de ocupação prioritária e preferencial (Figura 5), de acordo com o disposto no art. 23 do PDPP, com os seguintes critérios:

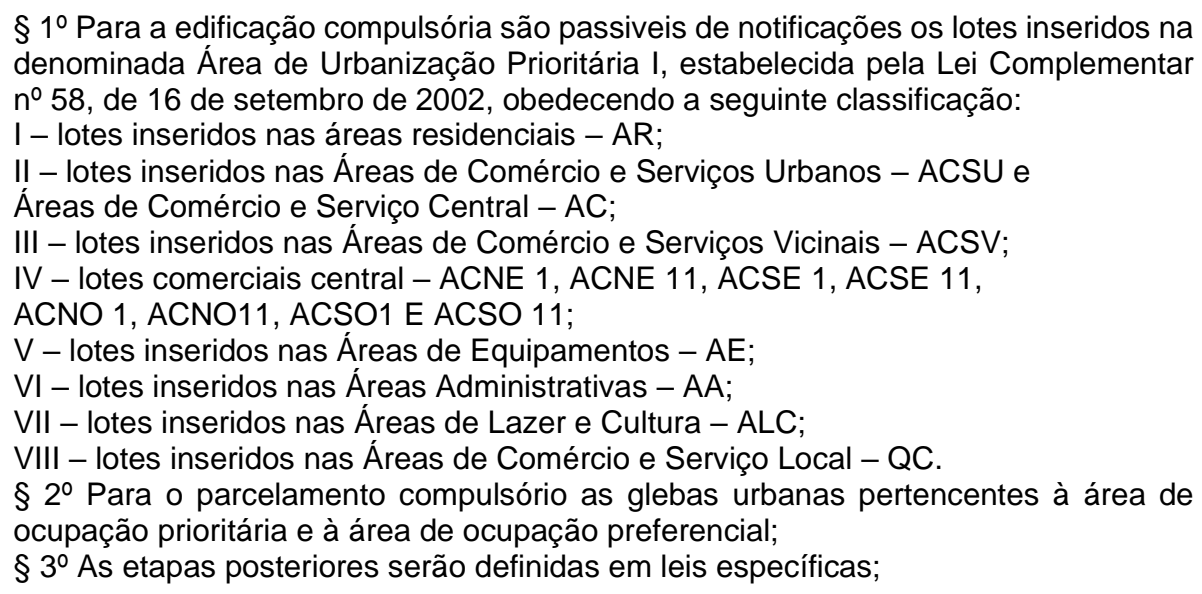

A lei considerou nesta primeira etapa, o parcelamento compulsório voltado para todas as áreas de ocupação prioritária e preferenciais (Figura 5) e para edificação compulsória restringiu a primeira etapa às áreas mais centralizadas, parcela da cidade localizada no plano urbanístico original, que seriam as faixas próximas às principais avenidas Teotônio Segurado e JK, dotados de infraestrutura urbana, na área denominada cadastralmente como "plano diretor norte e sul". Entende-se que a estratégia de dividir em etapas de aplicação, estabelecendo inicialmente a notificação dos lotes mais próximos aos principais eixos viários e de transporte, bem como à infraestrutura foi interessante no sentido de tornar o instrumento viável para a aplicação, tendo em vista que a quantidade excessiva de vazios urbanos.

Não se trata de fazer incidir o instrumento apenas naqueles setores da cidade de interesse do mercado imobiliário ou outros agentes, se essas regiões não forem aquelas que se deseja ocupar ou adensar a partir de uma lógica de construção de cidades mais justas e ambientalmente equilibradas. (IPEA, 2015, p. 74).

Apesar da Lei que regulamenta o PEUC ser de 2009, o município iniciou as notificações em 2011, tendo notificado naquele ano 250 proprietários, contudo as notificações não foram averbadas em cartório, o 
que causou o vício nos atos praticados e acarretou no cancelamento de todas. "Em dezembro de 2013, o município retomou os procedimentos, tendo efetuado notificações aos proprietários de 463 imóveis" (IPEA, 2015, p. 34).

Segundo dados da Divisão de IPTU Progressivo da Secretaria de Finanças de Palmas ${ }^{4}$, em 2015 iniciou a primeira etapa de cobrança do IPTU de forma progressiva, incidindo sob 205 imóveis que não cumpriam a sua função social. No ano de 2016 a segunda etapa de progressividade foi lançada para 149 imóveis, o que significa que 54 imóveis saíram da progressividade por cumprimento da função social. Neste mesmo ano foram lançados em primeira progressividade 161 imóveis. Em 2017 os imóveis em que a cobrança iniciou em 2015 foram para terceira etapa de progressividade, totalizando ainda 113 imóveis, a segunda progressividade alcançou 124 imóveis e ainda entraram mais 130 para a cobrança da $1^{\underline{a}}$ etapa de progressividade (PALMAS, 2019).

No ano de 2018 a cobrança continuou, sendo que 30 imóveis, dos primeiros notificados, se mantiveram sem cumprimento da função social da propriedade, entrando para a quarta progressividade, 90 imóveis foram para terceira etapa, 83 para a segunda e 126 entraram na primeira etapa de progressividade.

Ao todo, 328 imóveis estavam em processo de aplicação do IPTU progressivo no tempo em 2018, dos quais somente 46 são de empresas (IDEM). Cabe destacar que a empresa que possui a maior quantidade de imóveis com cobrança do instrumento (doze imóveis), detém ao todo 445 imóveis no município, foi a responsável por grande parte das obras de construção da cidade, e recebeu áreas em forma de pagamento. A empresa que possui a segunda maior quantidade de imóveis possui 137. Ressalta-se que um único proprietário possui 138 imóveis vagos no município, sendo somente 3 com a cobrança do instrumento. Dos 30 proprietários que possuem mais de dez imóveis em Palmas somente 11 são empresas (pessoa jurídica), 19 são pessoas físicas. Observa-se com os dados (Tabela 01) que não se trata somente do mercado imobiliário e sim de uma cultura de acumulação de lotes para especulação imobiliária. Na tabela abaixo classificamos a quantidade de lotes por proprietário, segundo pessoa física ou jurídica.

Tabela 01 - Quantidade de Proprietários com imóveis em execução e cobrança do IPTU Progressivo no Tempo em 2018, segundo quantidade de imóveis.

\begin{tabular}{cccc}
\hline Quantidade de lotes & Quantidade de proprietários & Pessoa física & Pessoa jurídica \\
\hline acima de 100 lotes & 4 & 1 & 3 \\
\hline de 50 a 100 lotes & 3 & 1 & 2 \\
\hline de 20 a 49 lotes & 6 & 3 & 3 \\
\hline de 10 a 19 lotes & 17 & 14 & 3 \\
\hline de 7 a 9 lotes & 18 & 16 & 2 \\
\hline de 4 a 6 lotes & 54 & 49 & 5 \\
\hline de 1 a 3 lotes & 166 & 138 & 28 \\
\hline Total & 268 & 222 & 46
\end{tabular}

Fonte: Divisão de IPTU Progressivo - Secretaria de Finanças. Elaborada pelos autores (2019).

Em junho de 2017 a Prefeitura instituiu o Programa de Urbanização de Palmas - PEU, Lei Complementar nํ 376/2017. Dentre os objetivos do programa está: "permitir uma ocupação planejada das áreas não parceladas ou não ocupadas, com etapas de implantação ao longo do tempo" (PALMAS, 2017, Art. $\left.2^{\circ}\right)$. Apesar dos demais objetivos serem relacionados à promoção do ordenamento da cidade, a Lei colabora para o não cumprimento da função social da propriedade, à medida em que confunde o conceito ao permitir o parcelamento das glebas em etapas com o prazo de até 20 anos, sendo 10\% a cada 2 anos, conforme pode-se verificar no Artigo $5^{\circ}$, citado abaixo.

A inclusão de áreas dentro do PEU permite:

$(\ldots)$

\footnotetext{
${ }^{4}$ Relatório de Lançamento de IPTU Progressivo da Secretaria de Finanças da Prefeitura Municipal de Palmas. (2019)
} 
II - a execução de parcelamentos do solo por etapas, com prazo total limitado a 20 (vinte) anos;

$\S 1^{\circ}$ Os parcelamentos do solo de que trata o inciso II do caput podem prever o cronograma de execução por etapas, de acordo com o seguinte:

I - mínimo de $10 \%$ (dez por cento) de implantação a cada 2 (dois) anos; para aqueles situados nas áreas urbanas de que trata 0 art. $3^{\circ}$ desta Lei Complementar;

Apesar da Lei em nenhum momento citar que as áreas incluídas no programa passam a cumprir a sua função social, a Prefeitura Municipal entende que o Parcelamento compulsório deixou de incidir sobre estas áreas, retirando-as da cobrança progressiva do IPTU, promovendo assim a manutenção dos vazios urbanos por mais 20 anos, o que significa que os objetivos de ocupação dos vazios urbanos foram descartados, configurando uma estratégia para burlar a legislação e criar empecilhos à continuidade da aplicação do instrumento.

Em 2018 foi aprovada a revisão do Plano Diretor Participativo de Palmas, Lei Complementar no 400/2018. Esta Lei revisou o Plano Diretor aprovado em 2007 (Lei Complementar 155/2007) e apesar de manter a nomenclatura, esta versão não foi elaborada com a mesma metodologia de participação do primeiro, que contou com a atuação efetiva de entidades da sociedade civil, que além de participarem de um curso de pós-graduação contratado pela Prefeitura, também participaram de mais de 30 audiências regionais e temáticas. Já a última revisão (2018) não houve participação efetiva de movimentos sociais organizados e observou-se uma participação "forçada" da equipe de servidores contratados e comissionados da Prefeitura Municipal. Observa-se também que a metodologia das audiências não possibilitou espaços para a fala dos participantes. É importante observar também que o município realizou reuniões temáticas com empresários, com membros da academia e com o Conselho de Desenvolvimento Urbano, separadamente, de modo que os interesses foram tratados de forma individual e não coletiva.

Mesmo mantendo a nomenclatura e o discurso de revisão, a Lei 400/2018 apresenta outros conceitos, outra metodologia e desconsidera as estratégias estabelecidas no plano anterior, o que pode ser observado, por exemplo na definição das regiões de planejamento e no macrozoneamento do município. $\mathrm{O}$ novo plano desconsidera as áreas prioritárias e preferenciais de ocupação (Figura 06), que na nossa avaliação eram essenciais para garantir o adensamento, tendo em vista que continuam com uma ocupação rarefeita, passando a incidir somente na Macrozona de Ordenamento Controlado (Figura 07), que é uma área muito extensa do município, praticamente toda a área do perímetro urbano estabelecida no plano anterior.

A lei estabelece que o "parcelamento, a edificação ou a utilização compulsórios poderão ser aplicados nos imóveis não edificados, subutilizados ou não utilizados localizados na Macrozona de Ordenamento Controlado" e especifica algumas áreas que estariam isentas da aplicação, quais sejam:

I - com função ambiental essencial, tecnicamente comprovada pelo órgão municipal competente;

II - de interesse do patrimônio cultural ou ambiental;

III - não edificado, parcialmente ocupado ou vazio, com atividade econômica que requeira espaços livres para o seu funcionamento;

IV - imóveis com exploração de produtos hortifrutigranjeiros vinculados a programas de abastecimento alimentar, devidamente registrados nos órgãos competentes.

Vale ressaltar também que a Lei aumentou consideravelmente o perímetro urbano do município, incorporando toda a área destacada na Figura 07, como Macrozona de Ordenamento Condicionado ao seu perímetro, caracterizando assim um contrassenso da estratégia de ordenamento da cidade, buscando a ocupação sustentável do território. 


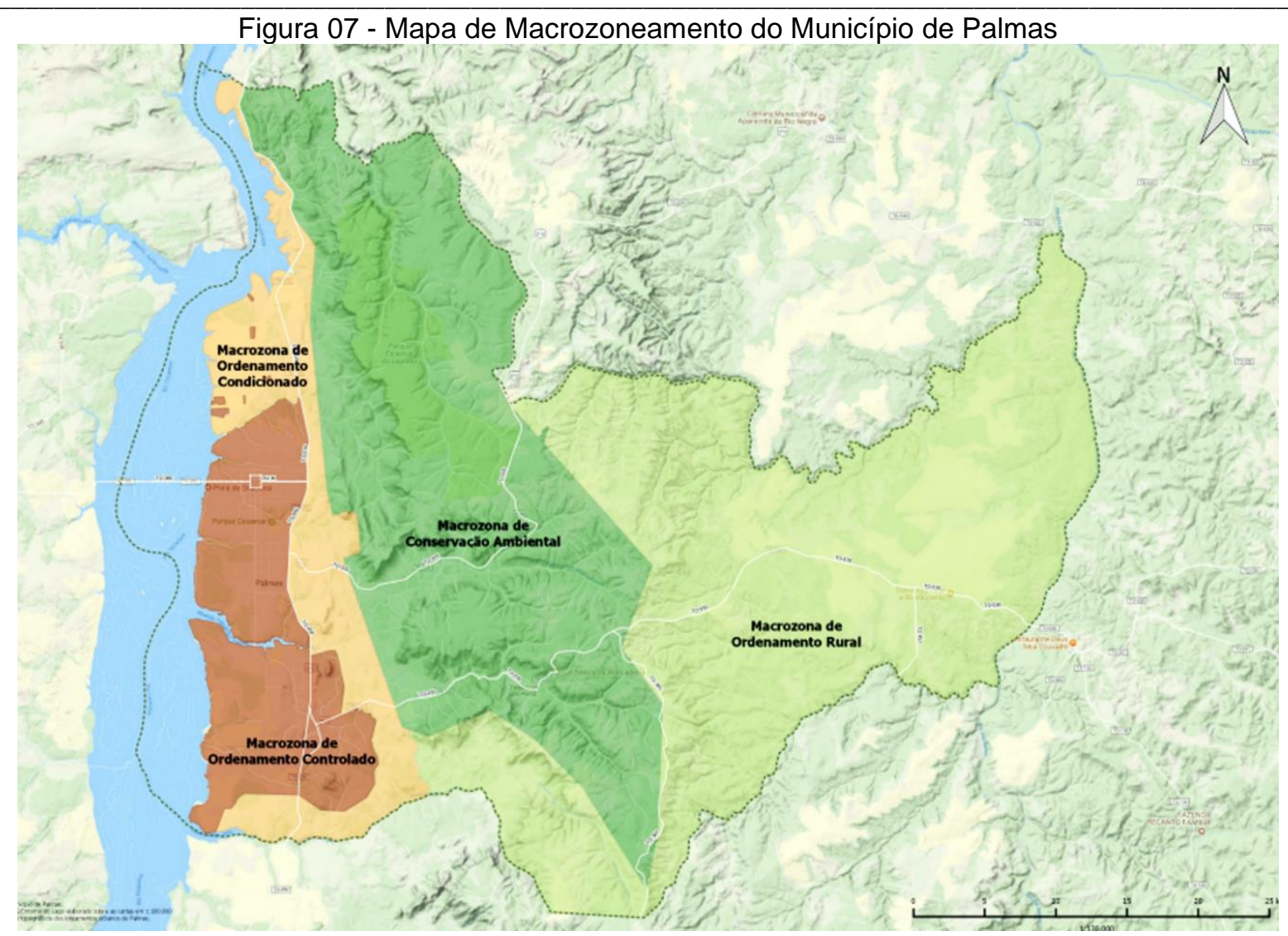

Fonte: GeoPalmas, Prefeitura de Palmas (2018)

O Novo Plano Diretor também conceitua no $\S 1^{0}$ do Art. 242, imóvel subutilizado e/ou não utilizado, sendo:

I - aquele cuja área construída seja inferior a 10\% (dez por cento) do potencial construtivo permitido para edificação no lote;

II - aquele cuja área construída seja igual ou superior à estabelecida no inciso I, porém abrigue atividade econômica notoriamente incompatível com o porte da edificação por período superior a 2 (dois) anos;

III - aquele cujo investimento na edificação for inferior ao preço do lote;

IV - aquele com edificações desocupadas por um período igual ou superior a 5 (cinco) anos;

V - edificação em ruínas ou que tenha sido objeto de demolição, abandono, desabamento ou incêndio;

VI - lotes ou glebas vazias em áreas dotadas de infraestrutura básica, tais como abastecimento de água e esgotamento sanitário, energia elétrica e acesso por vias pavimentadas e transporte público, a uma distância inferior a 800 metros;

VII - o imóvel urbano com área igual ou inferior a $5.000,00 \mathrm{~m}^{2}$ (cinco mil metros quadrados), com coeficiência de aproveitamento igual a zero; (redação da lei original, alterado pela Lei 411/2018)

VIII - a edificação abandonada ou desocupada há mais de 2 (dois) anos, independente da área construída.

Cabe destacar que o Plano Diretor foi alterado pela Lei oํ 411/2018, em dezembro de 2018, o que parece não fazer nenhum sentido, a medida em que o que se altera é o inciso VII do parágrafo $1^{\circ}$ do artigo 242, citado acima, que passa a vigorar com a seguinte redação: "o imóvel urbano com área igual ou superior a $5.000 \mathrm{~m}^{2}$ (cinco mil metros quadrados)", passando esse tipo de imóvel a fazer parte daqueles considerados não utilizados e/ou subutilizados.

Infere-se pelas matérias publicadas e entrevistas concedidas à imprensa pela Prefeita da Capital, Cinthia Ribeiro, que a Prefeitura objetivava alterar os incisos do caput do artigo 242, para que o PEUC 
pudesse incidir somente em imóveis acima de cinco mil metros quadrados, o que demonstra a intensão da Gestão de burlar a lei, desvirtuando os seus objetivos.

\begin{abstract}
A valoração progressiva do Imposto Predial e Territorial Urbano (IPTU), em Palmas, passou a contemplar somente imóveis sem edificação com área igual ou superior a 5 mil metros quadrados. A medida passou a vigorar a partir de 1ำ de janeiro de 2019, após aprovação da Câmara Municipal, e quer coibir a utilização de grandes glebas especulação imobiliária e permanência de vazios urbanos numa capital em pleno desenvolvimento.

A retirada de imóveis com área inferior a 5 mil metros quadrados, no entendimento da prefeita Cinthia Ribeiro, torna o imposto mais acessível a contribuintes que não são detentores de grandes extensões de área. ${ }^{5}$
\end{abstract}

O entendimento da Prefeita municipal, explicitado na matéria publicada, demonstra total falta de compromisso com a ocupação ordenada do território, desconsiderando todos objetivos do instrumento para beneficiar os proprietários de imóveis que que não cumprem a sua função social, na demonstração mais elucidativa do Estado Patrimonialista.

O novo Plano Diretor, apresenta uma concepção divergente da lei de 2007, pois além de ampliar consideravelmente o Perímetro Urbano do Município, aumentando ainda mais a possibilidade da dispersão urbana, o processo desconsiderou os instrumentos da política urbana que estavam em aplicação, como o PEUC e o IPTU Progressivo no tempo, objeto deste estudo. A Lei $n \circ 0$ 400/2018 torna sem efeito a aplicação dos instrumentos citados, uma vez que altera o zoneamento e delimita toda a área do plano urbanístico original para a sua aplicação (Macrozona de Ordenamento Controlado Figura 07), desconsiderando as áreas delimitadas pela Lei no 195/2009, não apresentando metodologia de aplicação, proposta de áreas prioritárias, remetendo a sua aplicação a outra legislação específica e revogando as leis anteriores, o que demonstra o descompasso entre o que se identificou de problemas, objetivos e os instrumentos propostos para o ordenamento da cidade.

O que podemos constatar de todo o processo de revisão do plano diretor e nas mais recentes intensões do executivo municipal é que os interesses da reprodução do capital se sobrepõe aos interesses da coletividade, mantendo as desigualdades e a segregação da população de baixa renda, prevalecendo, como pode-se observar a lógica de atuação do estado patrimonialista que promove a valorização do capital imobiliário em detrimento de uma ocupação justa, sustentável e ordenada do território.

\title{
CONSIDERAÇÕES FINAIS
}

É importante observar em Palmas, que os agentes imobiliários/fundiários historicamente possuem grande influência sob o território, a disputa pela terra faz parte da gênese do processo de ocupação e produção do seu espaço urbano e por isso o cumprimento da função social da cidade e da propriedade estão sempre em ataque. O Estado e os agentes dos capital neste processo estão em constante diálogo e seus interesses frequentemente se assemelham.

Pode-se observar no decorrer do processo de implementação do PEUC e IPTU Progressivo no tempo que o município de Palmas avança e recua constantemente na aplicação dos instrumentos, a sua formulação está sempre em disputa e constantemente predomina os interesses capitalistas em detrimento da maioria população, numa lógica constante de manutenção da segregação sócio-espacial enquanto estrutura de diferenciação social, e da especulação imobiliária, garantindo o lucro dos proprietários fundiários e a configuração de uma cidade insustentável, de ocupação esparsa, de baixa densidade e consequentemente com um altíssimo custo de manutenção.

A última revisão do marco legal urbano, que define o tamanho mínimo dos lotes onde incidirá a PEUC em cinco mil metros quadrados, acaba por enterrar de vez a utilização desse instrumento, que teria o potencial de ser muito importante na ordenação do território do município de Palmas, procurando reverter as suas contradições.

Logicamente que o processo de planejamento e gestão do território urbano não são alheios à conjuntura histórica, social e política, pois o espaço é planejado, produzido e reproduzido em função das relações sociais e ações do Estado sob o território. Apesar do avanço das normativas e regulações, que têm como pretenso objetivo a garantia de cidades mais justas, observa-se que o "motor" das

${ }^{5}$ Matéria publicada no site da Prefeitura Municipal de Palmas em 10 de janeiro de 2019. 
transformações urbanas é o sistema capitalista, que a partir de seus agentes estrutura e define a configuração do espaço.

Apesar do discurso da garantia do direito à cidade existente nas normativas urbanas, efetivamente os interesses dos agentes do capital prevalecem sobre o interesse comum, o que nos coloca em questionamento se o desafio para a garantia da função social da cidade e da propriedade seria possível ou se constitui como uma utopia no contexto de um país periférico do sistema capitalista.

\section{REFERÊNCIAS}

BASSUL, José Roberto. Reforma urbana e Estatuto da Cidade. EURE (Santiago), Santiago, v. 28, n. 8, 2002. https://doi.org/10.4067/S0250-71612002008400008

BAZOLLI, J. A. Parcelamento, Edificação e Utilização Compulsórios (PEUC): avaliação e resultados da aplicação em Palmas-TO. Direito da Cidade, v. 8, 2016. https://doi.org/10.12957/rdc.2016.23493

BRASIL. Constituição da República Federativa do Brasil, 1988.

BRASIL. Estatuto da Cidade. Lei no 10.257, de 10 Julho 2001.

CARLOS, Ana Fani A. A cidade. 8ª Edição São Paulo: Editora Contexto, 2007.

CASTELLS, Manuel. A Questão urbana. Rio de Janeiro: Paz e Terra, 2009.

CORDEIRO, Beatriz Barbosa. Parque Linear Córrego Brejo Comprido: a água como elemento cotidiano em paisagens urbanas. Monografia de Graduação. Curso de Arquitetura e Urbanismo, Universidade Federal do Tocantins, UFT, Palmas, TO, 2019.

CORIOLANO, Germana Pires. Plano Diretor Participativo de Palmas: análise da aplicação de instrumentos urbanísticos para a redução das desigualdades socioterritoriais. Dissertação (Mestrado em Desenvolvimento Regional). Universidade Federal do Tocantins. PPGDR/UFT: Palmas-TO, 2011.

CORIOLANO, G. P.; RODRIGUES, W; OLIVEIRA, A. F. Estatuto da Cidade e seus instrumentos de combate às desigualdades socioterritoriais: o Plano Diretor Participativo de Palmas (TO). Urbe Revista Brasileira de Gestão Urbana, v.5, n.2, 2013, p.131-145, 2013. https://doi.org/10.7213/urbe.05.002.AC04

CORREA, Roberto Lobato. O Espaço Urbano. São Paulo: Ed. Ática, 1989.

DUQUE BRASIL, Flavia de Paula. Democracia e participação social: A Construção de Avanços Democratizantes nas Políticas Urbanas Pós-1980, Tese (doutorado) Faculdade de Filosofia e Ciências Humanas. UFMG, Belo Horizonte, 2011.

GRAZIA, Grazia de. Reforma urbana e Estatuto da cidade. In: RIBEIRO, Luiz César de Queiroz; CARDOSO, Adauto Lúcio. Reforma urbana e gestão democrática: promessas e desafios do Estatuto da Cidade. Rio de Janeiro: Revan, p. 53-71. 2003.

HARVEY, David. A produção capitalista do espaço. $2^{\text {a }}$ Edição. São Paulo: Annablume. 2006

LEFEBVRE, Henri. A cidade do capital. Rio de Janeiro: DP\&A, 1999.

O Direito a Cidade. São Paulo: Ed. Centauro (5ª Edição), 2009.

MARICATO, Ermínia. As idéias fora do lugar e o lugar fora das idéias: Planejamento urbano no Brasil. In: A Cidade do pensamento único. - Desmanchando consensos. Petrópolis, Rio de Janeiro: Vozes, 2000.

MORAES, Lúcia Maria. A segregação planejada: Goiânia, Brasília e Palmas. Goiânia: Editora da UCG, 2003.

PALMAS, Prefeitura Municipal. IPTU Progressivo passa a atingir somente imóveis não edificados de grande extensão na Capital. Publicação de 10 de janeiro de 2019. https://www.palmas.to.gov.br/secretaria/financas/noticia/1509617/iptu-progressivo-passa-a-atingirsomente-imoveis-nao-edificados-de-grande-extensao-na-capital/ acesso em: 09/06/2019.

Plano Estratégico Municipal Assentamentos Precários. Palmas, TO, 2001.

.Lei complementar № 155, de 28 de dezembro de 2007. Dispõe sobre a política urbana no município de Palmas, 2007. 
. Caderno de Revisão do Plano Diretor de Palmas (mimeo), (2005).

Lei Municipal n. 368, de 17 de fev. de 1993. Dispõe sobre a divisão da Área Urbana da Sede do Município de Palmas em Zonas de Uso e dá outras providências, 1993.

Lei Municipal n. 468, de 06 de jan, de 1994. Aprova o Plano Diretor Urbanístico de Palmas (PDUP) e dispõe sobre a divisão do solo do município, para fins urbanos, 1994.

Lei complementar № 155, de 28 de dezembro de 2007. Dispõe sobre a política urbana no município de Palmas, 2007.

. Lei Complementar 376/2017. Instituiu o Programa de Urbanização de Palmas - PEU, 2017.

Lei Complementar n 400/2018 - Plano Diretor Participativo de Palmas, 2018.

Relatório de Lançamento de IPTU Progressivo no Tempo. Divisão do IPTU Progressivo Secretaria Municipal de Finanças; (mimeo), 2019.

PALMAS; BID; POLIS. Plano de Ação Palmas Sustentável,2015.

REDE DE AVALIAÇÃO E CAPACITAÇÃO PARA A IMPLEMENTAÇÃO DOS PLANOS DIRETORES PARTICIPATIVOS. Roteiro para Avaliação dos Planos Diretores. (Documento eletrônico). 2008.

RIBEIRO, Luiz Cesar de Queiroz. O Estatuto da Cidade e a questão urbana brasileira. In: RIBEIRO, Luiz C. de Q.; CARDOSO, Adauto L. (orgs.). Reforma Urbana e gestão democrática: promessas e desafios do Estatuto da Cidade. Rio de Janeiro: Revan/FASE, 2003.

RIBEIRO, Luiz Cesar Q. Segregação residencial: teorias, conceitos e técnicas. In: MOYSÉS, Aristides (org.). Cidade, segregação urbana e planejamento. Goiânia: Ed. da UCG, 2005.

ROLNIK, Raquel. A Construção de uma política fundiária e de planejamento urbano para o país: avanços e desafios. In: Planos Diretores Municipais: novos conceitos de planejamento territorial. São Paulo: Annablume, 2007.

SANTOS JUNIOR, O. A. e Montandon, D. T. (orgs.). Os planos diretores municipais pós-Estatuto da Cidade: balanço critico e perspectivas. Rio de Janeiro: Letra Capital: Observatório das Cidades: IPPUR/UFRJ, 2011.

SOUZA, Marcelo Lopes de. Mudar a cidade: uma introdução crítica ao planejamento e à gestão urbanos. Rio de Janeiro: Bertrand Brasil, 2010.

VILLAÇA, F. Espaço intra-urbano no Brasil. São Paulo: Studio Nobel: FAPESP: Lincoln Institute, 1998.

Recebido em: 20/09/2020

Aceito para publicação em: 20/11/2020 